\title{
Carbon mineralization and microbial activity in agricultural topsoil and subsoil as regulated by root nitrogen and recalcitrant carbon concentrations
}

\author{
Zhi Liang (iD - Lars Elsgaard • Mette Haubjerg Nicolaisen • \\ Annemette Lyhne-Kjærbye • Jørgen Eivind Olesen
}

Received: 12 June 2018 / Accepted: 18 September 2018

(C) Springer Nature Switzerland AG 2018

\begin{abstract}
Aims Mechanisms of subsoil carbon sequestration from deep-rooted plants are elusive, but may contribute to climate change mitigation. This study addressed the role of root chemistry on carbon mineralization and microbiology in a temperate agricultural subsoil (60 and $300 \mathrm{~cm}$ depth) compared to topsoil (20 cm depth).

Methods Roots from different plant species were chemically characterized and root-induced $\mathrm{CO}_{2}$ production was measured in controlled soil incubations (20 weeks). Total carbon losses, $\beta$-glucosidase activity, carbon substrate utilization, and bacterial gene copy numbers were determined. After 20 weeks, resultant carbon mineralization responses to mineral nitrogen $(\mathrm{N})$ were tested.

Results Root-induced carbon losses were significantly lower in subsoils (32-41\%) than in topsoil (58\%). Carbon losses varied according to root chemistry and were mainly linked to root $\mathrm{N}$ concentration for subsoils and to lignin and hemicellulose concentration for topsoil.
\end{abstract}

Responsible Editor: Jennifer Powers.

Electronic supplementary material The online version of this article (https://doi.org/10.1007/s11104-018-3826-z) contains supplementary material, which is available to authorized users.

Z. Liang $(\bowtie) \cdot$ L. Elsgaard $\cdot$ J. E. Olesen

Department of Agroecology, Aarhus University, Blichers Allé 20, 8830 Tjele, Denmark

e-mail: zhi.liang@agro.au.dk

M. H. Nicolaisen · A. Lyhne-Kjærbye

Department of Plant and Environmental Science, University of Copenhagen, Thorvaldsensvej 40, 1871

Frederiksberg C, Denmark
Increases in $\beta$-glucosidase activity and bacterial numbers in subsoils were also linked to root $\mathrm{N}$ concentration. Added mineral $\mathrm{N}$ preferentially stimulated $\mathrm{CO}_{2}$ production from roots with low concentrations of $\mathrm{N}$, lignin and hemicellulose.

Conclusions The results were compatible with a concept of $\mathrm{N}$ availability and chemically recalcitrant root compounds interacting to control subsoil carbon decomposition. Implications for carbon sequestration from deep-rooted plants are discussed.

Keywords Root chemistry · Nitrogen · Lignin · Carbon mineralization $\cdot$ Subsoil

\section{Introduction}

Sustainable food production systems are required to meet the global food demand arising from the projected population increase to 9 billion people by 2050 (Godfray et al. 2010). Increasing crop yields on existing farmland is essential, but may be challenging without compromising environmental quality (Pretty 2008). For example, intensive cereal cropping systems are often associated with nitrate $\left(\mathrm{NO}_{3}{ }^{-}\right)$leaching, soil acidification, and gaseous nitrous oxide $\left(\mathrm{N}_{2} \mathrm{O}\right)$ emissions due to high nitrogen $(\mathrm{N})$ inputs and insufficient duration of vegetation cover to retain $\mathrm{N}$ in the agroecosystem $(\mathrm{Ju}$ et al. 2009). Also, intensive cropping systems may lead to net mineralization and losses of soil organic carbon (SOC), which may threaten soil qualities and functions 
(Powlson et al. 2011) and further contribute to increasing atmospheric carbon dioxide $\left(\mathrm{CO}_{2}\right)$ concentrations.

Among sustainable management options to improve food production systems is the exploitation of subsoil resources (e.g., water and nutrients) by deep-rooted crops (Lynch and Wojciechowski 2015). Although not precisely defined, subsoil generally refers to soil below the $\mathrm{O}$ and/or A horizon, and deep-rooted crops have roots below the typical rooting depth of $<1 \mathrm{~m}$ for common cultivated agricultural crops (Maeght et al. 2013). Resource exploitation by deep-rooted crops could be important in systems with low reliance on external inputs, but also in intensive cropping systems where nutrients leached below the typical rooting depth can be assimilated rather than lost to aquatic ecosystems (Canadell et al. 1996; Ribaudo et al. 2011). Deployment of deep-rooted crops has further been suggested to contribute to climate change mitigation by increasing $\mathrm{CO}_{2}$ assimilation and by transferring root biomass and exudates into deep soil layers, where eventual sequestration of SOC may occur (Chirinda et al. 2014; Lorenz and Lal 2005).

Despite the importance of subsoils in enhancing crop yields and carbon sequestration, there are still major uncertainties concerning the mechanisms controlling carbon decomposition and SOC stabilization through deployment of deep-rooted crops (Rumpel and KögelKnabner 2011). Basically, soil carbon sequestration is determined by the balance between carbon input and losses (Amundson 2001). Therefore, sequestering subsoil carbon could be achieved through higher inputs in combination with slow mineralization of root-derived organic carbon (Lorenz and Lal 2005). Recent studies have suggested that decomposition of root carbon to some extent is regulated by inherent root chemical differences related to fast or slow degradation kinetics, such as contents of lignin, polysaccharides, polyphenols, and soluble fractions as well as $\mathrm{C} / \mathrm{N}$ ratios (Prieto et al. 2016; Zhang and Wang 2015). Yet, prediction of root decomposition as function of chemical quality is complex; moreover eventual carbon stabilization may depend on microbial growth and activity with products of anabolism forming the primary long-term stabilized carbon compounds (Cotrufo et al. 2015; Liang et al. 2017). Especially for subsoils, where the inherent microbial biomass and activity is generally low (Fierer et al. 2003b; Taylor et al.
2002), the interactions between root-derived carbon input, microbial physiology, and SOC turnover have to be further elucidated for exploitation of agroecosystems in climate change mitigation.

The aim of the present study was to specify the role of root chemical composition on carbon mineralization dynamics in topsoil and subsoil horizons of a temperate agricultural sandy loam soil. Different plant roots were chemically characterized and introduced in soil horizons down to $300 \mathrm{~cm}$ depth in controlled incubation experiments to trace the resulting net carbon mineralization. Also, the influence of root and soluble carbon input on microbial processes in these soil compartments was examined and, in particular, the role of root $\mathrm{N}$ content for co-stimulation of net carbon mineralization and microbial enzyme activity was addressed.

\section{Materials and methods}

Soil profile and soil sampling

Soil was sampled in December 2015 from an excavated soil profile $(0-300 \mathrm{~cm})$ at an unfertilized grass field at Foulumgaard Experimental Station, Denmark (56 29’ N, $\left.9^{\circ} 34^{\prime} \mathrm{E}\right)$. The area has Atlantic climate with mean annual air temperature of $7.3{ }^{\circ} \mathrm{C}$ and precipitation of $704 \mathrm{~mm}$ (Olesen et al. 2000). The soil type was a typical moraine deposit with an upper black Ap horizon $(0-40 \mathrm{~cm})$ representing a sandy loam classified as Typic Hapludult. Below the Ap horizon was a slightly weathered $\mathrm{Bw}_{1}$ horizon $(40-70 \mathrm{~cm})$ overlaying a $\mathrm{Bw}_{2}$ horizon showing signs of clay accumulation $(70-100 \mathrm{~cm})$. Root fragments were observed in the $\mathrm{A}$ and $\mathrm{Bw}_{1}$ horizons. The lower part of the soil profile was a uniform clayey $\mathrm{C}$ horizon (100$300 \mathrm{~cm}$ ). Both the $\mathrm{B}$ and $\mathrm{C}$ horizons were light brown without visual signs of anoxic conditions (such as pseudogleys). This was corroborated by in situ redox potentials (Eh) of 575-654 $\mathrm{mV}$ throughout the soil profile as measured by platinum electrode pushed into freshly exposed soil surfaces (Kjaergaard et al. 2012).

Soil was sampled from seven depths of 20,60, 100, 150, 200, 250, and $300 \mathrm{~cm}$. Three soil samples $(n=3)$ were collected at each depth, i.e., representing one sample from each of three sides of the soil excavation. Soils for bulk density analyses were sampled in $100-\mathrm{cm}^{3}$ metal 
rings, whereas soils ( $\sim 100 \mathrm{~g})$ for phospholipid fatty acid (PLFA) analyses were sampled in zip-locked plastic bags and stored at $2{ }^{\circ} \mathrm{C}$ until analysis (within 4 weeks). All other analyses were done with soil samples $(\sim 2 \mathrm{~kg})$ that were air dried, sieved $(<2 \mathrm{~mm})$, and stored $\left(2{ }^{\circ} \mathrm{C}\right)$ until use (within 4-12 weeks).

Physico-chemical and microbial soil profile analyses

Total carbon (TC) and N (TN) were determined using a Thermo Flash 2000 NC Analyzer (Thermo Fisher Scientific, Delft, The Netherlands) as previously described (Taghizadeh-Toosi et al. 2014). The soil samples were devoid of carbonates (effervescence test) and TC was considered SOC. Total phosphorous (TP) was measured colorimetrically (Spectronic Helios Alpha, Thermo Scientific) using the molybdic blue method (ISO 2004) after digestion $\left(1 \mathrm{~h}, 250^{\circ} \mathrm{C}\right)$ of $0.1 \mathrm{~g}$ ball-milled soil in $1 \mathrm{~mL}$ concentrated $\mathrm{HClO}_{4}$. Total S was measured with pooled soil samples from each depth by combustion of 1-g ballmilled soil samples at $1100{ }^{\circ} \mathrm{C}$ on a vario MAX cube CNS analyzer (Elementar Analysensysteme GmbH, Germany). Mineral $\mathrm{N}$ (i.e., $\mathrm{NO}_{3}-\mathrm{N}$ and $\mathrm{NH}_{4}-\mathrm{N}$ ), Olsen-P, and available $\mathrm{K}$ weres determined as previously described after soil extraction (30 min) with $1 \mathrm{M} \mathrm{KCl}, 0.5 \mathrm{M}$ $\mathrm{NaHCO}_{3}$, and $0.5 M \mathrm{NH}_{4} \mathrm{Ac}$, respectively (Sørensen and Bülow-Olsen 1994). Soil $\mathrm{pH}$ was measured by glass electrode in a soil-to-solution ratio of 1:2.5 (wt/wt) using $0.01 \mathrm{M} \mathrm{CaCl}_{2}$. Bulk density and gravimetric water content were determined after oven drying at $105^{\circ} \mathrm{C}$ for $24 \mathrm{~h}$. Soil texture was analysed by wet sieving and hydrometer methods (Gee and Bauder 1986) with pooled soil samples from each depth, and results were reported as proportions of clay $(<2 \mu \mathrm{m})$, silt $(2-63 \mu \mathrm{m})$, and sand (63$2000 \mu \mathrm{m})$.

Microbial analyses included arylsulfatase activity, $\beta$ glucosidase activity, and PLFA concentrations. Arylsulfatase activity was measured with duplicate 2-g samples soil mixed with $4 \mathrm{~mL}$ acetate buffer $(0.5 \mathrm{M}$, $\mathrm{pH}$ 5.8) and $1 \mathrm{~mL} p$-nitrophenyl-sulfate $(20 \mathrm{mM})$ as previously described in detail by Elsgaard et al. (2002). $\beta$-Glucosidase activity was determined with duplicate 1-g soil samples amended with $4 \mathrm{~mL}$ modified universal buffer (pH 6) and $1 \mathrm{~mL} p$-nitrophenyl- $\beta$-D-glucoside $(25 \mathrm{~m} M)$ according to Eivazi and Tabatabai (1988). Samples were incubated on a rotary shaker at $150 \mathrm{rev} \mathrm{min}^{-1}$ for $2 \mathrm{~h}$ at $20^{\circ} \mathrm{C}$ and the reaction was stopped by adding $4 \mathrm{~mL}$ TRIS buffer (pH 12) and $1 \mathrm{~mL} \mathrm{CaCl}_{2}$, followed by centrifugation (10 min, $3000 \mathrm{~g}$ ). Absorbance of the supernatant was measured at $400 \mathrm{~nm}$ for quantification of produced $p$-nitrophenol (NP). PLFA concentrations were analysed according to Petersen et al. (2002). Briefly, PLFAs were extracted from $2.5 \mathrm{~g}$ fresh soil with a modified single-phase Bligh-Dyer extraction followed by solid-phase extraction on 100-mg silica columns. PLFAs were subjected to alkaline trans-esterification and resulting fatty acid methyl esters (FAMEs) were dissolved in hexane for analysis by gas-chromatography (GC) coupled to mass spectrometry (Department of Biology, Lund University, Sweden). Internal standards with methyl tridecanoate and methyl nonadecanoate were added for quantification of FAMEs. Nomenclature and use of FAMEs as biomarkers was adapted from Fierer et al. (2003b), distinguishing between signatures for gram-positive bacteria $(i-\mathrm{C} 14: 0, i-\mathrm{C} 15: 0, a-\mathrm{C} 15: 0, i$ $\mathrm{C} 16: 0, i$-C17:0, $a$-C17:0), gram-negative bacteria (cy-

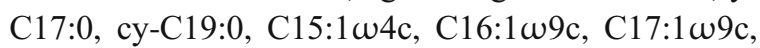

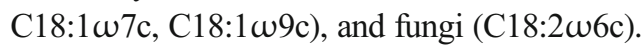

\section{Plant roots}

For isolation of root biomasses with different chemical properties, five plant species from different taxonomic families were cultured (Table 1), representing species of Asteraceae (Artemisia vulgaris L.), Brassicaceae (Isatis tinctoria L.), Fabaceae (Medicago sativa L.), Polygonaceae (Rumex crispus L.) and Poaceae (Miscanthus $\times$ giganteus Keng). The plants were grown in a laboratory set-up with 13-cm diameter and 1-m deep darkened Plexiglas cylinders, where the upper part $(0-$ $30 \mathrm{~cm}$ ) was filled with loamy topsoil and the lower part $(30-100 \mathrm{~cm})$ was filled with sandy subsoil. Three cylinders were prepared for each plant species. After a growth period of two months (May to July 2015), roots were collected from the topsoil and subsoil by separating the soil under running water on a sieve with $0.425 \mathrm{~mm}$ diameter openings. The recovered roots were dried at $60{ }^{\circ} \mathrm{C}(48 \mathrm{~h})$ for determination of dry weight. The dried root residues were ground $(<2 \mathrm{~mm})$ and stored in sealed plastic bags for soil incubation experiments. Subsamples of $5 \mathrm{~g}$ were ball-milled for analysis of root chemical composition. 
Root chemistry

TC and TN concentrations were analysed for topsoil and subsoil roots from each plant cylinder (Thermo Flash 2000 NC Analyzer) and corrected for ash fractions, determined after ignition in a muffle oven $(6 \mathrm{~h}$, $550^{\circ} \mathrm{C}$ ). Fractions of soluble materials (SOL), hemicellulose (HEM), cellulose (CEL), and lignin (LIG) were determined by fiber digestion methods (Van Soest 1963). Root samples ( $0.5 \mathrm{~g})$ were digested by boiling for $1 \mathrm{~h}$ in $100 \mathrm{~mL}$ of neutral detergent solution (for recovery of neutral detergent fibers, NDF) or in $100 \mathrm{~mL}$ of acid detergent solution (for recovery of acid detergent fibers, ADF) using a Fibertec 2010 Auto Fiber Analysis System (FOSS, Hillerød, Denmark). After digestion, suspensions were vacuum-filtered in a filter crucible and recovered fibers were rinsed repeatedly with hot distilled water and acetone. The fiber materials were dried overnight $\left(105{ }^{\circ} \mathrm{C}\right)$ and weighed; subsequently ash fractions were determined $\left(6 \mathrm{~h}, 550{ }^{\circ} \mathrm{C}\right)$. For determination of acid detergent lignin (ADL), a separate ADF digestion was followed by digestion with $12 \mathrm{M} \mathrm{H}_{2} \mathrm{SO}_{4}(24 \mathrm{~h})$ prior to further treatment. NDF, $\mathrm{ADF}$ and $\mathrm{ADL}$ were calculated as the respective weight percentage of recovered fiber materials (corrected for ash fractions) and used for assessment of SOL (100\% minus NDF), HEM (NDF minus ADF), CEL (ADF minus ADL), and LIG (ADL) according to Van Soest (1963).

Effect of root chemistry on carbon mineralization and soil microbiology

Incubation studies to measure carbon mineralization and related soil microbiology was performed with six selected root samples and excavated soil from the $\mathrm{A}(20 \mathrm{~cm})$, $\mathrm{B}(60 \mathrm{~cm})$, and $\mathrm{C}(300 \mathrm{~cm})$ horizons. Root samples were selected to represent divergent root chemical composition, rather than selecting specifically for topsoil or subsoil roots. For one species (M. sativa), topsoil and subsoil roots were mixed to provide sufficient root material for the incubation experiment.

The incubation experiment had a full factorial design with three replicates. Roots and the equivalent of $50 \mathrm{~g}$ dry soil were mixed in 130-mL glass flasks at a concentration of $2.5 \mathrm{mg}$ root $\mathrm{C} \mathrm{g}^{-1}$ soil (equal to $\sim 10 \mathrm{Mg} \mathrm{C}$ $\mathrm{ha}^{-1}$ ). The flasks were covered with parafilm punctured by a needle to allow gas exchange while minimizing moisture loss. The soil moisture was adjusted to $40 \%$ of water-holding capacity (WHC) and maintained throughout the incubation period ( 20 weeks) by weighing (weekly) and readjusting with deionized (DI) water. The packing density was 1.3 and $1.7 \mathrm{~g}$ soil $\mathrm{cm}^{-3}$ for topsoil and subsoils, respectively. Soil reference treatments were made without roots (i.e., with DI water only) and positive mineralization controls were made without roots, but with added glucose $\left(2.5 \mathrm{mg} \mathrm{C} \mathrm{g}^{-1}\right.$ soil $)$ and nutrient salts solutions $\left(\mathrm{KNO}_{3}, \mathrm{KH}_{2} \mathrm{PO}_{4}\right.$, and $\left.\mathrm{K}_{2} \mathrm{SO}_{4}\right)$, to a resulting $\mathrm{C}: \mathrm{N}: \mathrm{P}: \mathrm{S}$ ratio of 100:10:1:1 (glucosenutrient treatment; referred to as GN).

The treatments, as outlined above, were prepared in four complete sets (each with $n=3$ ), enabling four destructive samplings for soil TC and microbial analyses, i.e., initially ( $2 \mathrm{~h}$ after preparation) and after incubation for 1,5 and 20 weeks at $20{ }^{\circ} \mathrm{C}$ in the dark. Soil $\mathrm{CO}_{2}$ production (see below) was measured recurrently during the incubation period using the same set of incubation flasks; this set was used for the last destructive sampling. At destructive samplings, each soil sample was mixed and stored at $2{ }^{\circ} \mathrm{C}$ (less than 2 weeks) for soil microbial assays or frozen at $-80^{\circ} \mathrm{C}$ for subsequent TC and bacterial gene copy analyses.

\section{Carbon mineralization}

Rates of $\mathrm{CO}_{2}$ production was measured with a LI-COR 840 infrared gas analyzer (LI-COR, Inc., Lincoln, NE) coupled to a pump $\left(0.01 \mathrm{~L} \mathrm{~s}^{-1}\right)$ and a data logger (Kandel et al. 2016). The measuring frequency ranged from daily to monthly at the end of the experiment. Measurements were done by connecting the LI-COR to individual sample flasks via inlet and outlet tubing (inner diameter, $5 \mathrm{~mm}$ ) inserted through a rubber stopper fitting the flasks. $\mathrm{CO}_{2}$ concentrations were recorded at 1-s intervals for 1-5 min (depending on $\mathrm{CO}_{2}$ production rate). Resulting rates $\left(\mu \mathrm{g} \mathrm{CO}_{2}-\mathrm{C} \mathrm{g}^{-1}\right.$ soil $\mathrm{h}^{-1}$ ) were calculated based on slopes of linear regression.

To determine the total net carbon mineralization (i.e., root-induced carbon loss), TC in soil from all treatments were analysed (Thermo Flash $2000 \mathrm{NC}$ Analyzer) at destructive sampling times of 1 and 20 weeks. Rootinduced carbon losses, including potential priming effects, were calculated as the difference between nominally added TC and TC measured after 1 and 20 weeks 
Table 1 Identity, life cycle, and root distribution of the plant species cultivated for isolation of roots for incubation studies

\begin{tabular}{lllllll}
\hline Family & Species & Abbreviation & Common name & Usage & Life cycle $^{\mathrm{a}}$ & Root ratio $^{\mathrm{b}}$ \\
\hline Asteraceae & Artemisia vulgaris L. & Av & Mugwort & Culinary, medicinal & $\mathrm{P}$ & $0.7 \pm 0.1$ \\
Brassicaceae & Isatis tinctoria $\mathrm{L}$. & $\mathrm{It}$ & Dyer's woad & Blue dye, medicinal & $\mathrm{P}, \mathrm{B}$ & $4.3 \pm 0.6$ \\
Fabaceae & Medicago sativa $\mathrm{L}$. & $\mathrm{Ms}$ & Lucerne & Forage legume & $\mathrm{P}, \mathrm{A}$ & $1.7 \pm 0.5$ \\
Polygonaceae & Rumex crispus $\mathrm{L}$. & $\mathrm{Rc}$ & Curly dock & Wild leaf vegetable & $\mathrm{P}$ & $12.1 \pm 0.3$ \\
Poaceae & Miscanthus $\times$ giganteus Keng & $\mathrm{Mg}$ & Miscanthus & Energy crop & $\mathrm{P}$ & $1.1 \pm 0.3$ \\
\hline
\end{tabular}

${ }^{a} P$ perennial, $B$ biennial, $A$ annual. Some species may have varying life cycles

${ }^{\mathrm{b}}$ Root ratio indicates the ratio of root biomass in topsoil $(0-30 \mathrm{~cm})$ and subsoil (30-100). Data are mean \pm standard error of root biomass from three plant cylinders

of incubation. These root-induced carbon losses were corrected for carbon losses in reference treatments.

\section{Microbial activity}

Soil from destructive samplings was analysed for $\beta$ glucosidase activity (earlier described) and for carbon source utilization (CSU) using the MicroResp procedure (Campbell et al. 2003) with $0.3 \mathrm{~g}$ topsoil or $0.4 \mathrm{~g}$ subsoil in 1.2-mL deep-wells (96-well microtiter plates). Three carbon substrates (and DI water as reference) were tested, i.e., N-acetyl-D-glucosamine (NADG), D-glucose, and vanillin. The latter (a lignin degradation product) was included as representative of recalcitrant plant compounds (Banning et al. 2012). NADG and Dglucose were added in $25-\mu \mathrm{L}$ portions to deliver $30 \mathrm{mg}$ substrate $\mathrm{g}^{-1}$ soil water, whereas the less soluble vanillin was added to deliver $7.5 \mathrm{mg}$ substrate $\mathrm{g}^{-1}$ soil water. Final soil water contents corresponded to $\sim 60 \%$ WHC. The $\mathrm{CO}_{2}$ evolved from CSU during incubation $\left(4 \mathrm{~h}, 20^{\circ} \mathrm{C}\right)$ was quantified by spectrophotometric analysis of detector plates (Campbell et al. 2003) in a microplate reader at $570 \mathrm{~nm}$ (SPECTROstar Nano, BMG $\mathrm{LABTECH}$ ). A calibration curve was prepared from detector plates equilibrated with precise $\mathrm{CO}_{2}$ concentrations that were verified by GC analysis on an Agilent 7890 GC system (Petersen et al. 2012).

A repeated measurement of CSU was performed after 1 day of soil exposure to the carbon sources in the deep-wells, i.e., to allow for brief adaptation of the metabolic mineralization processes. For this purpose, and following the original MicroResp assay, the deepwell plates were covered with parafilm and placed at $20^{\circ} \mathrm{C}$ in the dark until MicroResp assays were repeated with fresh detector plates.

As a final assay, subsoils from the last destructive sampling (week 20) were conditioned for MicroResp and amended with $\mathrm{KNO}_{3}$ to $0.25 \mathrm{mg} \mathrm{N} \mathrm{g}^{-1}$ soil (but not with carbon substrates). The nitrate-induced respiratory response of residual carbon in the soil was followed by repeated MicroResp assays (as described above) during 12 days.

\section{Bacterial gene copies}

DNA was extracted from 7 to $10 \mathrm{~g}$ soil using PowerMax Soil DNA Isolation kit (MO BIO Laboratories, Inc.) following the manufacturers protocol. The concentration and purity of extracted DNA was assessed using a NanoDrop ND-1000 spectrophotometer (Thermo Fisher Scientific). Quantitative PCR (qPCR) was performed on a MX3000P using the Brilliant III Ultra Fast SYBR Green QPCR Master Mix (Agilent Technologies) and the universal 16S rDNA bacterial primers 907F 5'AAACTYAAAGGAATTGACGG-3' (Lane et al. 1985) and 1492R(1) 5'-GGTTACCTTGTTACGACTT3' (Turner et al. 1999). Each $20-\mu \mathrm{L}$ reaction contained $2 \mu \mathrm{L}$ of 1:10 diluted DNA extract, $1 \mu \mathrm{g} \mu \mathrm{L}^{-1}$ BSA (New England Biolabs, Inc.), $1 \times$ Master Mix, and $0.4 \mu M$ of each primer. Thermal cycling conditions were 3 min at $95{ }^{\circ} \mathrm{C}$ followed by 35 cycles of $15 \mathrm{~s}$ at $95^{\circ} \mathrm{C}$ and $20 \mathrm{~s}$ at $57^{\circ} \mathrm{C}$. A final melt curve was included according to the default settings of the MxPro qPCR software (Agilent Technologies). A plasmid standard curve was established based on the pCR 2.1 TOPO vector (Invitrogen Life Technologies) with a 


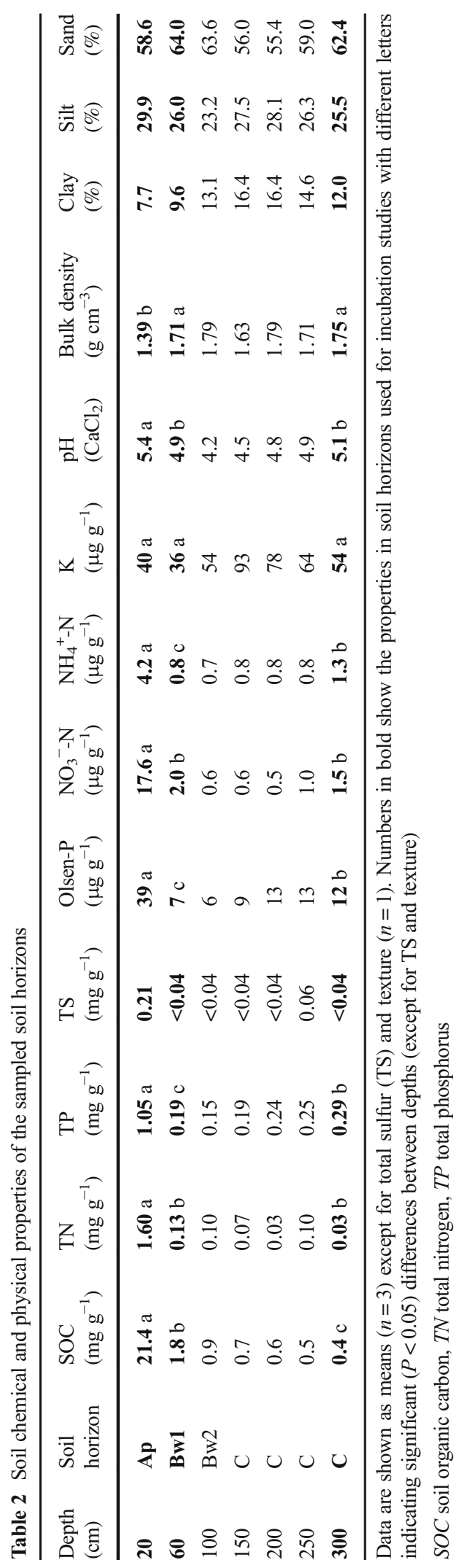


Pseudomonas putida mt2 16S rRNA gene insert. The range of the standard curve covered six orders of magnitude and revealed an efficiency of $72 \%$. From the quantification of 16S rRNA gene copies, bacterial cell numbers were estimated using the average value of 4.7 gene copies cell ${ }^{-1}$ from the Ribosomal RNA Database, rrnDB (Stoddard et al. 2014).

\section{Statistical analyses}

Measures of central tendency and dispersion were reported as means and standard error (SE) with $n=3$ unless otherwise indicated. One-way analysis of variance (ANOVA) was used to test the effect of soil depth on soil physico-chemical parameters. Student's $t$ test was used to test the difference between topsoil and subsoil root chemical compositions for individual plant species. Two-way ANOVA was used to test the effect of soil depth and treatment (root materials and $\mathrm{GN}$ ) on net carbon mineralization at week 1 and 20. Two-way ANOVA was also used to test bacterial gene copy numbers in relation to incubation time and treatments. Data for SOC and bacterial gene copy numbers were log transformed to comply with assumptions of normality and homoscedasticity (Kolmogorov-Smirnov test and Levene's test respectively; $P<0.05)$. Significant ANOVA tests $(P<0.05)$ were followed by post-hoc pairwise multiple comparisons using the Newman-Keuls test (Zar 2010). The relationships between root chemical composition and net carbon mineralization were analysed by Pearson productmoment correlation. All analyses were performed using SigmaPlot version 11.0 (Systat Software, Inc.).

\section{Results}

Soil profile characteristics

Topsoil at the sandy loam profile had $21.4 \mathrm{mg} \mathrm{SOC} \mathrm{g}^{-1}$ and $1.6 \mathrm{mg} \mathrm{TN} \mathrm{g}^{-1}$ (Table 2), which together with the clay content (7.7\%), pH (5.4), and bulk density (1.4 g soil $\mathrm{cm}^{-3}$ ) were typical for arable soils in the study area (Olesen et al. 2000). SOC and TN declined rapidly with soil depth to $\leq 0.9 \mathrm{mg} \mathrm{SOC} \mathrm{g}^{-1}$ and $\leq 0.1 \mathrm{mg} \mathrm{TN} \mathrm{g}^{-1}$ at $100-300 \mathrm{~cm}$, whereas clay contents and bulk density increased in subsoils as compared to topsoil (Table 2).

Enzyme activities in the topsoil were distinctly higher than in the subsoil B horizon, and virtually undetectable in the $\mathrm{C}$ horizon below $100 \mathrm{~cm}$ depth (Fig. S1a). Profiles of PLFA concentrations aligned with this pattern, reflecting a rapidly decreasing microbial biomass with depth both for biomarkers attributed to gram-negative bacteria, gram-positive bacteria, and fungi (Fig. S1b, c).

\section{Root chemistry}

The five plant species (Table 3 ) had rather similar carbon concentration both in topsoil roots (419-452 $\mathrm{mg} \mathrm{C} \mathrm{g}^{-1}$ )

Table 3 Concentrations of total carbon (TC), total nitrogen (TN), and fiber fractions in topsoil (top) and subsoil (sub) roots of the cultivated plant species

\begin{tabular}{|c|c|c|c|c|c|c|c|c|c|c|c|c|c|c|}
\hline \multirow[t]{2}{*}{ Plant species } & \multicolumn{2}{|c|}{$\begin{array}{l}\mathrm{TC} \\
\left(\mathrm{mg} \mathrm{g}^{-1}\right)\end{array}$} & \multicolumn{2}{|c|}{$\begin{array}{l}\mathrm{TN} \\
\left(\mathrm{mg} \mathrm{g}^{-1}\right)\end{array}$} & \multicolumn{2}{|c|}{$\begin{array}{l}\mathrm{C} / \mathrm{N} \\
\text { ratio }\end{array}$} & \multicolumn{2}{|c|}{$\begin{array}{l}\text { SOL } \\
\left(\mathrm{mg} \mathrm{g}^{-1}\right)\end{array}$} & \multicolumn{2}{|c|}{$\begin{array}{l}\text { HEM } \\
\left(\mathrm{mg} \mathrm{g}^{-1}\right)\end{array}$} & \multicolumn{2}{|c|}{$\begin{array}{l}\text { CEL } \\
\left(\mathrm{mg} \mathrm{g}^{-1}\right)\end{array}$} & \multicolumn{2}{|c|}{$\begin{array}{l}\text { LIG } \\
\left(\mathrm{mg} \mathrm{g}^{-1}\right)\end{array}$} \\
\hline & top & sub & top & sub & top & sub & top & sub & top & sub & top & sub & top & sub \\
\hline$A v^{a}$ & $424^{*}$ & 400 & $7^{*}$ & 5 & 57 & $85^{*}$ & 671 & $880^{*}$ & 32 & 3 & $191^{*}$ & 77 & $106^{*}$ & 44 \\
\hline It & 419 & 422 & 11 & 12 & 39 & 35 & $781^{*}$ & 713 & 65 & 86 & 124 & 134 & 29 & $65^{*}$ \\
\hline $\mathrm{Ms}^{\mathrm{b}}$ & $435^{*}$ & 418 & 24 & 23 & 18 & 18 & 721 & $809^{*}$ & $60^{*}$ & 29 & 180 & 116 & 39 & 46 \\
\hline $\mathrm{Rc}$ & 427 & 431 & 6 & $11^{*}$ & $69^{*}$ & 40 & $742^{*}$ & 595 & $130^{*}$ & 84 & 69 & $175^{*}$ & 59 & $148^{*}$ \\
\hline $\mathrm{Mg}$ & $452^{*}$ & 426 & 8 & 6 & 56 & 71 & 305 & $528^{*}$ & $257^{*}$ & 222 & $277^{*}$ & 138 & $162^{*}$ & 105 \\
\hline
\end{tabular}

Data are shown as means $(n=3)$; coefficients of variation were generally less than $15 \%$. Significant differences $(P<0.05)$ between individual chemical properties in topsoil and subsoil roots are indicated by an asterisk for the higher value. Numbers in bold show the root samples used for incubation studies. Plant species and abbreviations: Av, A. vulgaris; It, I. tinctoria; Ms, M. sativa; Rc, R. crispus; Mg, M. × giganteus

SOL solubles, HEM hemicellulose, CEL cellulose, $L I G$ lignin

${ }^{a}$ For Av, roots from topsoil and subsoil were used separately for incubation studies

${ }^{\mathrm{b}}$ For Ms, roots from topsoil and subsoil were pooled (1:1) to obtain sufficient materials for incubation studies 


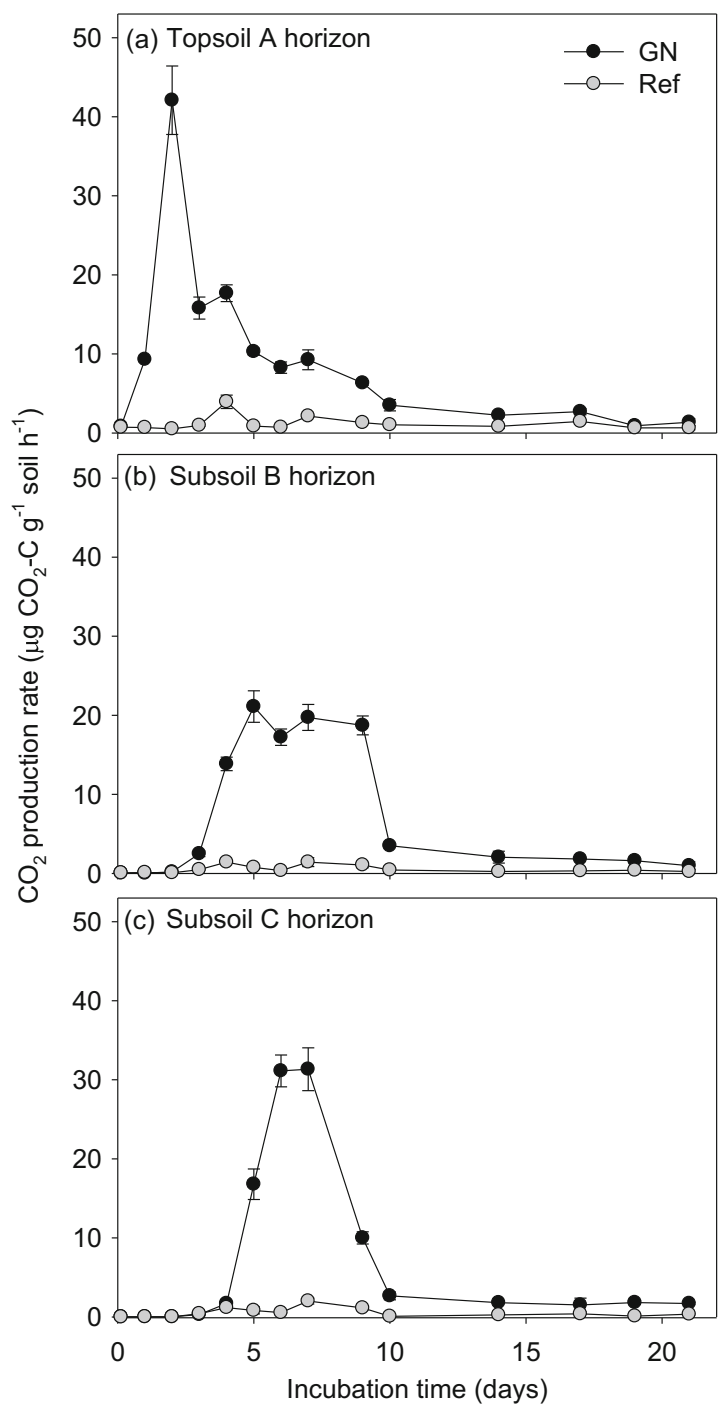

Fig. 1 Dynamics of $\mathrm{CO}_{2}$ production in topsoil A horizon $(20 \mathrm{~cm})$, subsoil B horizon $(60 \mathrm{~cm})$, and subsoil $\mathrm{C}$ horizon $(300 \mathrm{~cm})$ in $(\mathbf{a}-\mathbf{c})$ reference (Ref, deionized water) and positive control treatments (GN, glucose and nutrients), and in (d-f) treatments with roots

and subsoil roots (400-431 $\left.\mathrm{mg} \mathrm{C} \mathrm{g}^{-1}\right)$. However, TN concentrations were divergent among the plant species, ranging from 5 to $24 \mathrm{mg} \mathrm{N} \mathrm{g}^{-1}$ with highest concentration for $M$. sativa. The resulting $\mathrm{C} / \mathrm{N}$ ratios showed clear difference between $M$. sativa $(\mathrm{C} / \mathrm{N}$ ratio, 18$)$ and the other plant species ( $\mathrm{C} / \mathrm{N}$ ratio, 35-85). Further, $\mathrm{C} / \mathrm{N}$ ratios were typically similar or higher for subsoil roots than for topsoil roots (except for R. crispus).
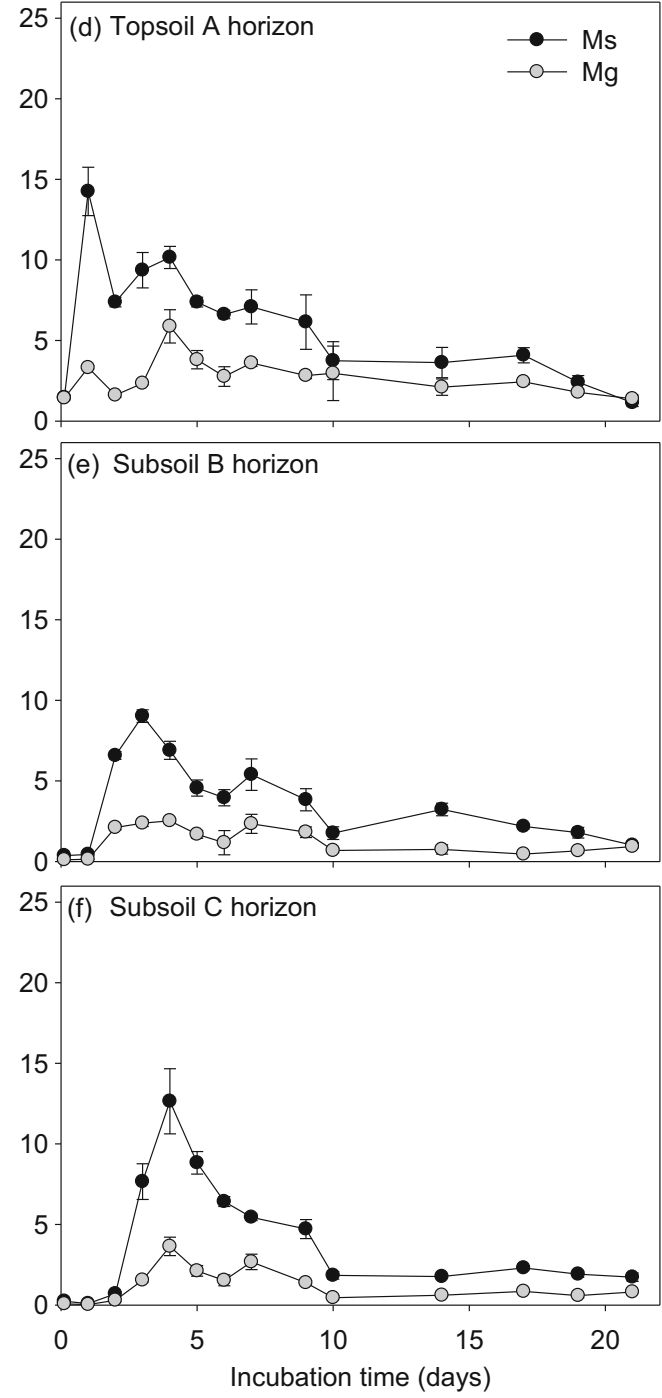

from M. sativa $(\mathrm{Ms})$ and $M . \times$ giganteus $(\mathrm{Mg})$. Data are shown as means \pm standard error $(n=3)$ for the first 3 weeks of a 20-week incubation period. Note the difference in y-axis scales between left and right panels

SOL fractions were the main constituent (528$880 \mathrm{mg} \mathrm{g}^{-1}$ ) of root biomasses, except for $M$. $\times$ giganteus topsoil roots $\left(305 \mathrm{mg} \mathrm{g}^{-1}\right)$. Concentrations of CEL typically ranged from 124 to $277 \mathrm{mg} \mathrm{g}^{-1}$ in topsoil roots and decreased with root depth, except for $R$. crispus. HEM and LIG concentrations in topsoil roots ranged from 32 to $257 \mathrm{mg} \mathrm{g}^{-1}$ and $29-162 \mathrm{mg} \mathrm{g}^{-1}$, respectively, with highest concentrations in $M . \times$ giganteus. In subsoil roots, 


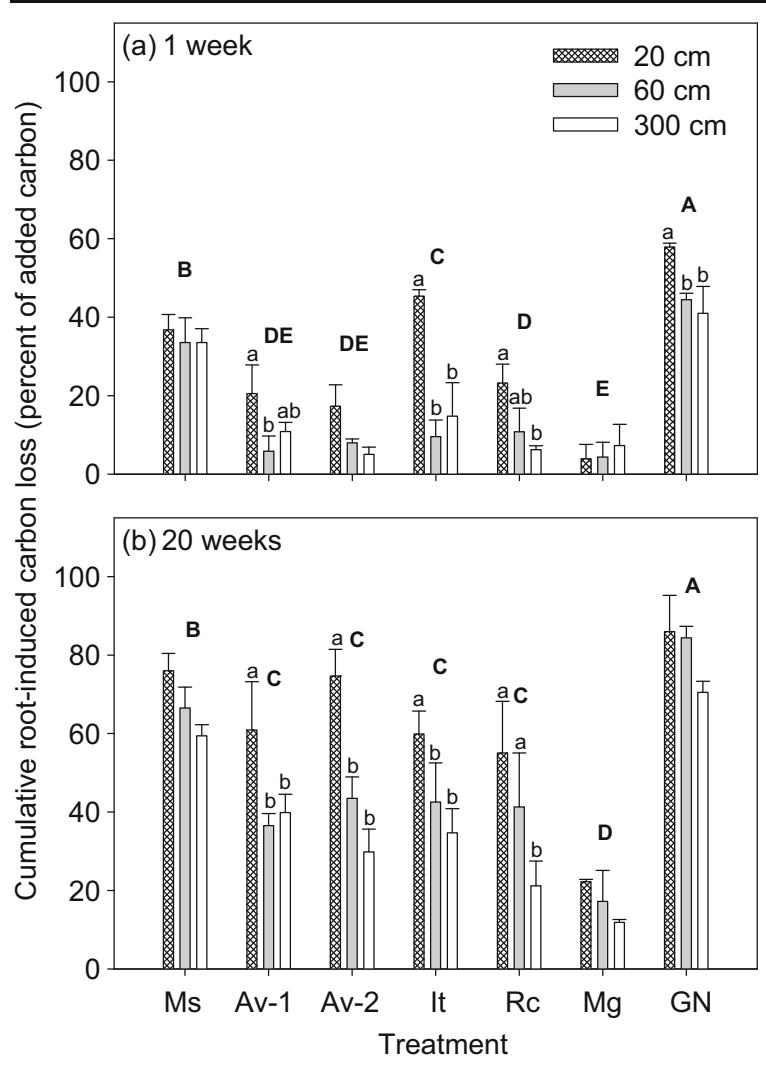

Fig. 2 Cumulative root-induced carbon losses from topsoil and subsoils after incubation with root biomass or with positive control treatment (GN, glucose and nutrients) for (a) 1 week and (b) 20 weeks. Root-induced carbon losses, including potential priming effects, were calculated from the difference between nominally added TC and TC measured after 1 and 20 weeks of incubation. Data are means \pm standard error $(n=3)$. Uppercase letters indicate significant differences $(P<0.05)$ between treatments; lowercase letters indicate significant differences (if any) between soil depths within treatments. Root biomasses: Ms, M. sativa; Av, A. vulgaris; It, I. tinctoria; Rc, R. crispus; Mg, M. $\times$ giganteus. Av-1 and Av-2 denote Av roots from topsoil and subsoil, respectively

HEM concentrations were highest in $M . \times$ giganteus (222 $\mathrm{mg} \mathrm{g}^{-1}$ ), whereas the highest LIG concentrations were in R. crispus (148 $\mathrm{mg} \mathrm{g}^{-1}$ ).

Effects of root chemistry on carbon mineralization

\section{Mineralization patterns and root-induced carbon loss}

Rates of $\mathrm{CO}_{2}$ production in topsoil reference treatments were typically less than $1-2 \mu \mathrm{g} \mathrm{C} \mathrm{g}^{-1}$ soil $\mathrm{h}^{-1}$ during the incubation period, with an average of $0.6 \mu \mathrm{g} \mathrm{C} \mathrm{g}^{-1}$ soil h$^{-1}$
(Fig. 1a and S2a). In subsoils, reference mineralization rates were likewise low, typically less than $0.5 \mu \mathrm{g} \mathrm{C} \mathrm{g}^{-1}$ soil $\mathrm{h}^{-1}$ (Fig. 1b,c and S2b,c). Positive controls (GN treatments) showed high and immediately induced $\mathrm{CO}_{2}$ mineralization rates in topsoil with a maximum of $42.1 \mu \mathrm{g} \mathrm{C}$ $\mathrm{g}^{-1}$ soil $\mathrm{h}^{-1}$ (Fig. 1a). For subsoils, a lower but still substantial mineralization rate in GN treatments occurred after a lag-phase of 4-5 days (Fig. 1b, c). Mineralization rates in all GN treatments decreased to background levels within 2 weeks and stabilized throughout the incubation period (Fig. 1 and S2).

Root biomass stimulated $\mathrm{CO}_{2}$ production in topsoil already after 1 day of incubation (Fig. $1 \mathrm{~d}$ and $\mathrm{S} 2 \mathrm{~g}$ ); the effect was highest for M. sativa (14.3 $\mu \mathrm{g} \mathrm{C} \mathrm{g}^{-1}$ soil h$^{-1}$ ) and lowest for $M . \times$ giganteus $\left(3.3 \mu \mathrm{g} \mathrm{C} \mathrm{g}^{-1}\right.$ soil h$\left.^{-1}\right)$. A similar pattern was seen for subsoils after a lag-phase (23 days), i.e., with highest and lowest stimulation by M. sativa and M. $\times$ giganteus, respectively (Fig. 1e, $\mathrm{f}$ and S2 h,i). In both topsoil and subsoil, carbon mineralization generally decreased to constant rates within few weeks (Fig. 1 and S2).

TC analyses a few hours after root and GN amendments quantitatively recovered the nominally added carbon concentrations (Table S1) with mean \pm SE of $101.1 \pm 0.5 \%$ $(n=21)$. Subsequent cumulative carbon losses from topsoil GN treatments (positive controls) after 1 and 20 weeks represented 58 and $86 \%$ of the added carbon, respectively (Fig. 2a, b). After 1 week, the losses in subsoils were lower than in topsoils (Fig. 2a), but after 20 weeks the losses were similar, i.e., reaching $71-84 \%$ of the added carbon (Fig. 2b). For treatments with added root biomass, cumulative carbon losses varied with highest losses for $M$. sativa (60-75\% after 20 weeks) and lowest losses for $M$. × giganteus (10-21\% after 20 weeks). Across the root treatments, the net carbon losses in topsoil were higher than in subsoils after 20 weeks $(P<0.01)$, i.e., with average losses of $58 \%, 41 \%$, and $32 \%$ in topsoil, subsoil B horizons, and subsoil C horizons, respectively. However, for $M$. sativa (high losses) and $M . \times$ giganteus (weak losses) the differences in carbon losses among soil horizons were nonsignificant.

\section{Correlation between carbon mineralization and root chemistry}

Cumulative carbon mineralization after 1 week, caused by roots in subsoils, was strongly correlated to root $\mathrm{TN}$ 
Table 4 Pearson correlation coefficients $(r)$ between root chemistry and root-induced carbon losses from topsoil and subsoil horizons after 1 and 20 weeks

\begin{tabular}{|c|c|c|c|c|c|c|c|}
\hline \multirow[t]{2}{*}{ Soil horizon } & \multirow[t]{2}{*}{ Incubation } & \multicolumn{6}{|c|}{ Root chemical composition } \\
\hline & & $\mathrm{TN}$ & $\mathrm{C} / \mathrm{N}$ & LIG & LIG/N & HEM & CEL \\
\hline Topsoil A & 1 week & 0.57 & -0.62 & $-0.81^{(*)}$ & $-0.94^{* *}$ & -0.53 & -0.47 \\
\hline Subsoil B & 1 week & $0.91^{*}$ & -0.72 & -0.49 & -0.70 & -0.28 & -0.20 \\
\hline Subsoil C & 1 week & $0.99^{* * *}$ & $-0.91^{*}$ & -0.36 & -0.66 & -0.26 & 0.05 \\
\hline Topsoil A & 20 weeks & 0.31 & -0.12 & $-0.84^{*}$ & $-0.74^{(*)}$ & $-0.94^{* *}$ & -0.72 \\
\hline Subsoil B & 20 weeks & 0.69 & -0.50 & $-0.80^{(*)}$ & $-0.87^{*}$ & -0.68 & -0.57 \\
\hline Subsoil C & 20 weeks & $0.77^{(*)}$ & -0.67 & -0.55 & -0.71 & -0.70 & -0.20 \\
\hline
\end{tabular}

$T N$ total nitrogen, $C / N$ ratio of carbon to nitrogen, $L I G$ lignin, $L I G / N$ ratio of lignin to nitrogen, $H E M$ hemicellulose, $C E L$ cellulose. Significance of correlations are shown as $(*), P<0.10$; *, $P<0.05$; **, $P<0.01$; ***, $P<0.001$. Scatter plots between carbon losses and N and LIG indices are shown in Figs. S3 and S4

concentration $(r=0.91-0.99, P<0.05)$, whereas such correlation was weaker $(r=0.57)$ and non-significant in topsoil (Table 4). A similar, but less clear pattern was seen for the $\mathrm{C} / \mathrm{N}$ ratio, thus indicating a crucial role of the root $\mathrm{N}$ concentration for subsoil carbon mineralization. $\mathrm{Cu}-$ mulative carbon mineralization after 1 week correlated negatively with LIG and LIG/N ratio, but this was significant only in topsoil (Table 4). Correlations between carbon mineralization after 1 week and HEM and CEL were mostly negative, albeit weak and non-significant $(P \geq 0.28)$.

Cumulative carbon mineralization in topsoil after 20 weeks still was poorly correlated to root TN concentration and strongly (negatively) correlated to LIG (Table 4). Negative correlation to HEM $(r=0.94$, $P<0.01)$ suggested that this fraction also restricted root-induced carbon mineralization in topsoil after 20 weeks. For subsoils, the correlations between cumulative carbon mineralization and root $\mathrm{TN}$ concentrations were weaker after 20 weeks than after 1 week. However, negative correlations to $\mathrm{LIG}$ and $\mathrm{LIG} / \mathrm{N}$ ratio became stronger and significant at least in the subsoil B horizon (Table 4).

The role of $\mathrm{N}$ availability for carbon mineralization in subsoils was substantiated by marked stimulation in $\mathrm{CO}_{2}$ production when $\mathrm{NO}_{3}{ }^{-}$was added to subsoil treatments with $A$. vulgaris, I. tinctoria, and $R$. crispus roots after the 20-week incubation period (Fig. S5). Such an N-induced stimulation of $\mathrm{CO}_{2}$ production was absent in subsoils with GN, M. sativa, and M. × giganteus (Fig. S5), in accordance with higher microbial $\mathrm{N}$ availability (and carbon mineralization) during the preceding 20-week incubation period at least for GN and M. sativa.

Effects of root chemistry on soil microbiology

\section{$\beta$-Glucosidase activity}

The initial $\beta$-glucosidase activity across treatments was $11.3 \mu \mathrm{g} \mathrm{NP} \mathrm{g}^{-1} \mathrm{~h}^{-1}$ in topsoil, but more than 10 -fold lower in subsoils (Fig. 3a). This aligned with enzyme activities in the native soil profile (Fig. S1a). During incubation for 1,5 , and 20 weeks, $\beta$-glucosidase activity in topsoil treatments increased up to 3-fold (Fig. 3b, c and $\mathrm{d}$ ). In subsoil, $\beta$-glucosidase activity was only weakly stimulated after 1,5 , and 20 weeks in treatments with $A$. vulgaris and $R$. crispus, whereas notably $M$. sativa and positive controls (GN) showed a pronounced increase in enzyme activity (Fig. 3b, c and d). The highest stimulation of enzyme activity was consistently found in the subsoil $\mathrm{C}$ horizon (Fig. 3b, $\mathrm{c}$ and $\mathrm{d}$ ). The resulting $\beta$-glucosidase activity was strongly correlated to the root $\mathrm{TN}$ concentration with correlation coefficients of $r=0.81-0.97(P \leq 0.05)$ for the B horizon and $r=0.87-0.94(P \leq 0.02)$ for the $\mathrm{C}$ horizon (Fig. 4).

\section{Carbon source utilization}

After the 1 week soil incubation, the MicroResp CSU potential for glucose and NADG in topsoil (Fig. 5a, b) 

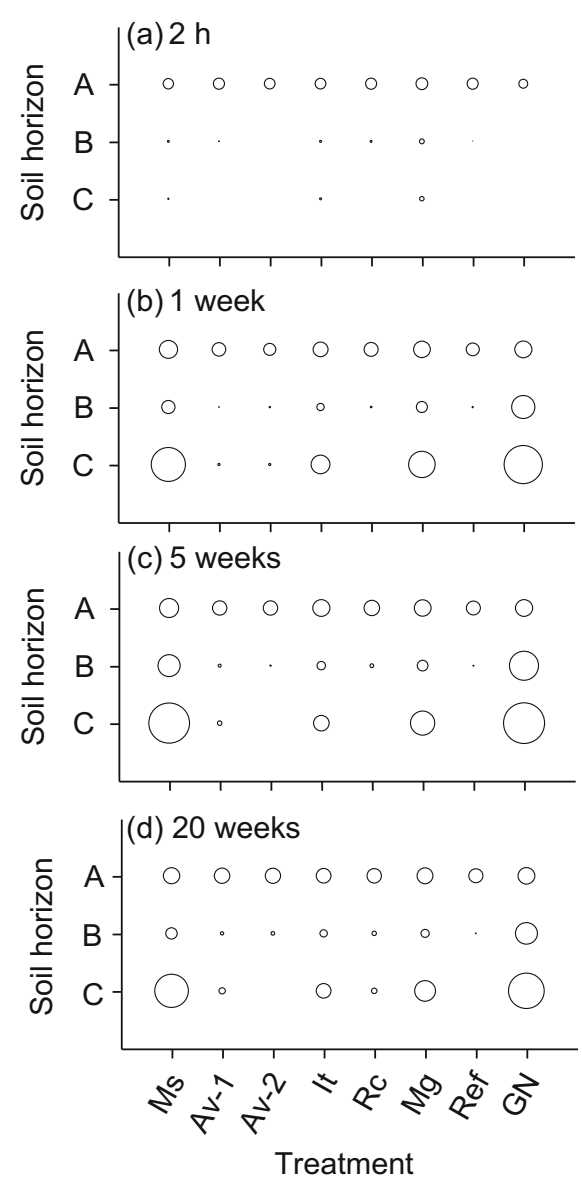

Fig. $3 \beta$-Glucosidase activity in topsoil (A horizon) and subsoils (B and C horizons) incubated for (a) $2 \mathrm{~h}$, (b) 1 week, (c) 5 weeks, and (d) 20 weeks with root biomass or with reference (Ref, deionized water) and positive control treatment (GN, glucose and nutrients). Symbol areas denote the $\beta$-glucosidase activity (maximum area, $126 \mu \mathrm{g}$ nitrophenol $\mathrm{g}^{-1}$ soil $^{-1}$ ). Root biomasses: Ms, M. sativa; Av, A. vulgaris; It, I. tinctoria; Rc, R. crispus; Mg, M. $\times$ giganteus. Av-1 and Av-2 denote Av roots from topsoil and subsoil, respectively

was low in reference treatment, highest in positive control (GN treatment), and intermediate in most root treatments. For corresponding subsoil assays, only GN and $M$. sativa treatments showed detectable CSU (Fig. 5a, b). With repeated MicroResp after 1 day of carbon source exposure, CSU potentials for glucose and notably NADG (Fig. 5d, e) were consistently high in topsoil across all treatments. Subsoil treatments generally showed a lower and varying mineralization potential, yet with more consistent rates for NADG than for glucose (Fig. 5d, e). The
$\mathrm{CO}_{2}$ production from vanillin was always negligible, i.e., indicating high persistence across all soil depths and treatments (Fig. 5c, f). Thus, neither foregoing soil incubation with root biomass nor subsequent 1-day exposure to vanillin resulted in substantial microbial vanillin mineralization.

The patterns of CSU in treatments incubated for $2 \mathrm{~h}$, 5 weeks, and 20 weeks (Fig. S6) resembled those for 1 week (Fig. 5), basically underlining the main results of weak instant CSU of glucose and NADG in subsoils, stimulated CSU after 1-day exposure notably to NADG, and virtual absence of vanillin mineralization.

\section{Bacterial gene copies}

Bacterial 16S rRNA gene copy numbers were quantified for topsoil $\mathrm{A}$ and subsoil $\mathrm{C}$ horizons incubated with roots of M. sativa, I. tinctoria, and R. crispus as well as reference treatments. Gene copy numbers in initial topsoil incubations corresponded to $0.5-0.8 \times 10^{9}$ cells g $^{-1}$ with no significant differences among the treatments (Fig. 6a). In subsoil, gene copy numbers were lower, by three orders of magnitude, corresponding $0.1-4.8 \times 10^{6}$ cells $\mathrm{g}^{-1}$ with the lowest numbers in reference treatments (Fig. 6b). After 1 week of incubation, the bacterial population in topsoil increased for all root treatments $\left(0.9-1.4 \times 10^{9}\right.$ cells $\left.\mathrm{g}^{-1}\right)$ compared to the reference $\left(0.5 \times 10^{9}\right.$ cells g $\left.^{-1}\right)$. A similar pattern was found in subsoil root treatments, but most conspicuously for $M$. sativa treatments where cell numbers increased by two orders of magnitude to $0.3 \times 10^{9}$ cells g $^{-1}$ (Fig. 6b).

\section{Discussion}

The studied topsoil and subsoils represented a typical sandy loam profile, which had developed under unfertilized grassland for about 20 years at a site previously under arable agriculture. The conspicuous declining depth distribution of SOC, TN, and microorganisms reflected the pattern of inputs of plant-derived carbon being highest at the soil surface (e.g., Heinze et al. 2018; Schrumpf et al. 2013). In this way, the soil profile resembles profiles from both sandy, loamy, and clayey soils, where microbial numbers and activities are often two to three orders of magnitude higher in topsoil than in 


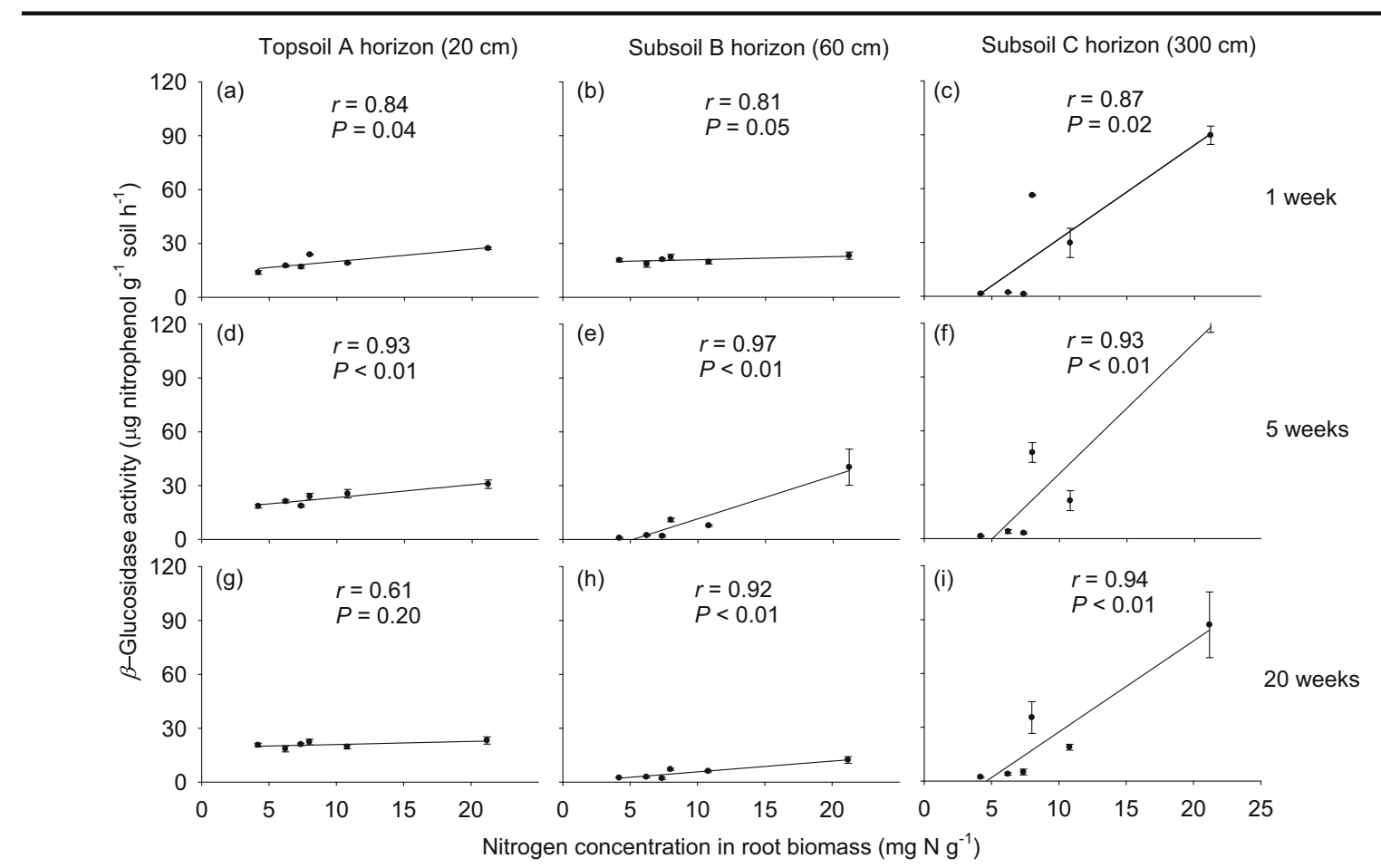

Fig. 4 Correlations between nitrogen $(\mathrm{N})$ concentration in root biomass and $\beta$-glucosidase activity after soil incubation for (a-c) 1 week, (d-f) 5 weeks, and (g-i) 20 weeks. Correlations are shown for incubated topsoil A horizon $(20 \mathrm{~cm})$, subsoil B horizon
$(60 \mathrm{~cm})$, and subsoil $\mathrm{C}$ horizon $(300 \mathrm{~cm})$. Data are means \pm standard error $(n=3)$. Pearson correlation coefficients $(r)$ and significance $(P)$ of correlations are shown in each panel subsoils (Fierer et al. 2003b; Heitkötter et al. 2017; Taylor et al. 2002; Vinther et al. 2001).

Roots with different chemical composition were isolated from five plant species including M. sativa, which is known for biological $\mathrm{N}$ fixation (Carlsson and HussDanell 2003). The $\mathrm{C} / \mathrm{N}$ ratio of the present $M$. sativa roots aligned with previous studies (Raiesi 2006) and was distinctly lower than $\mathrm{C} / \mathrm{N}$ ratios for the other plant species. In general, the average proportions of HEM, CEL and LIG in the roots across plant species and depths (97, 148 and $80 \mathrm{mg} \mathrm{g}^{-1}$, respectively) were at the lower end of values reported in previous studies (Aulen and Shipley 2012; Lindedam et al. 2009; Redin et al. 2014). This most likely reflected that roots were collected after a growth period of two months, when the plants were still in vegetative growth (Abiven et al. 2011; Picon-Cochard et al. 2012). Potential differences between new and older root biomass were not pursued, but the present study rather relied on selection of taxonomically different plant species to test the influence of chemically different roots on subsoil carbon mineralization and microbial dynamics.
Carbon mineralization in relation to root chemistry

Previous studies have suggested that simple chemical variables can be indicators of the decomposition rates when different litter types decompose in the same environment (Zhang and Wang 2015). In the present study, net carbon losses after 1 and 20 weeks varied among root treatments and were correlated to root chemistry, notably to TN concentrations in the case of subsoils (Table 4). Overall, the data suggested that LIG and HEM concentrations were important for controlling carbon mineralization rates in topsoil, whereas TN was important in subsoil with LIG content becoming more influential (negatively) over time. The importance of $\mathrm{N}$ limitation for carbon mineralization in subsoils was substantiated by MicroResp assays, where spiking with inorganic N (after the 20-weeks incubation period) stimulated carbon mineralization in N-poor root treatments, although not in the case of $M . \times$ giganteus (Fig. S5), which had the highest concentrations of LIG and HEM. This showed that factors other than $\mathrm{N}$ availability played a role in root decomposition (Aulen et al. 2012; Machinet et al. 2009), as also 

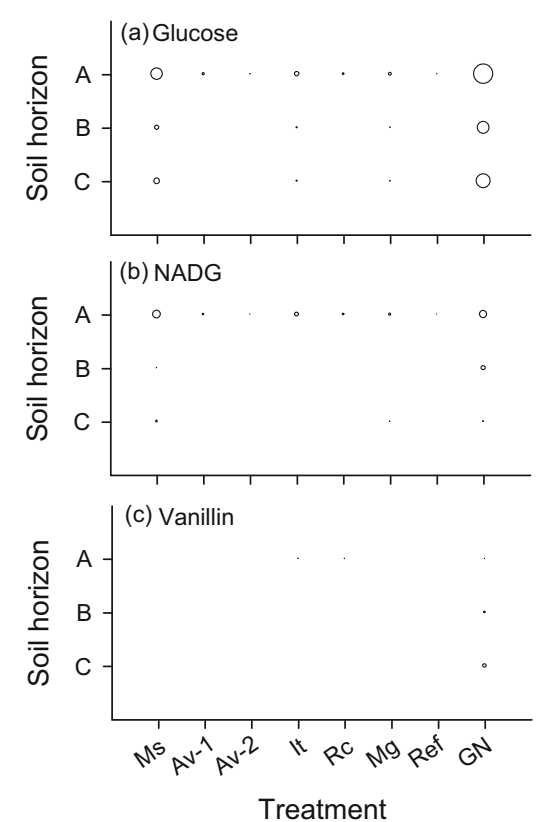

Fig. 5 Mineralization pattern of glucose, N-acetyl-Dglucosamine (NADG), and vanillin in topsoil (A horizon) and subsoils (B and $\mathrm{C}$ horizons). Carbon substrate utilization (CSU) was assayed by MicroResp with soil samples after incubation for 1 week with root biomass or with reference (Ref, deionized water) and positive control treatment (GN, glucose and nutrients). CSU

indicated by the negative correlation between resulting TC loss and LIG and HEM (Table 4). The weaker $\mathrm{CO}_{2}$ production (MicroResp) responses to $\mathrm{N}$ addition in treatments with $A$. vulgaris subsoil roots (106 $\mathrm{mg} \mathrm{LIG} \mathrm{g}^{-1}$ ) compared to topsoil roots $\left(44 \mathrm{mg} \mathrm{LIG} \mathrm{g}^{-1}\right.$ ) substantiated the role of LIG contents in root carbon turnover (Fig. S5). Several studies have demonstrated that lignin is recalcitrant and may reduce the microbial accessibility of polysaccharides through formation of links between lignin and polysaccharides (Berg and Laskowski 2005; Bertrand et al. 2006). The general absence of vanillin mineralization during MicroResp in the present study indicated that the soil microbiome was not specifically adapted to degradation of highly complex lignified carbon compounds. This may to some extent explain the highest retention of root carbon in the $M . \times$ giganteus treatments.

Carbon mineralization in topsoil and subsoils

Stimulated carbon mineralization occurred rapidly in topsoil after amendment of root biomass and GN, whereas a lag-phase of 4-5 days preceded substantial carbon mineralization in subsoils. The lag-phase could
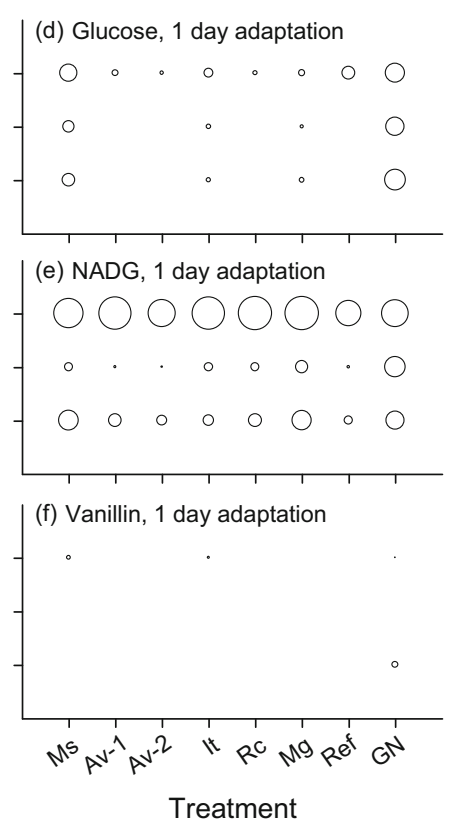

was assayed instantly (left panels) and after 1 day adaptation to glucose, NADG, and vanillin (right panels). Symbol areas denote the $\mathrm{CO}_{2}$ production rate (maximum area, $9.0 \mu \mathrm{g} \mathrm{CO}_{2}-\mathrm{C} \mathrm{g}^{-1}$ soil $\mathrm{h}^{-1}$ ). Root biomasses: Ms, M. sativa; Av, A. vulgaris; It, I. tinctoria; Rc, R. crispus; Mg, M. $\times$ giganteus. Av-1 and Av-2 denote Av roots from topsoil and subsoil, respectively

be related to proliferation or activation of a microbial community with sufficient metabolic enzyme capacity, which was already present in the topsoil where carbon inputs (in situ) occurred continually (Sanaullah et al. 2011). The duration of the lag-phase (days rather than hours), and the increase in bacterial gene copies after 1 week, aligned with microbial proliferation as the main source of increased carbon mineralization in subsoils (Alexander 1977). Input of carbon compounds (in situ) was highly restricted in the native subsoils, which developed under unfertilized grass, where roots were mainly present in the A horizon. Hence, energetic and/ or nutritional limitation likely constrained microbial growth and activity in the subsoils (Fierer et al. 2003a; Fontaine et al. 2007), which, however, were responsive to amendments of root biomass. The lag-phase observed was shorter than typically found under field conditions (Sanaullah et al. 2011), most likely reflecting the incubation procedures with optimal conditions of moisture and temperature, homogeneous admixture of the carbon compounds, and the conditioning (grounding) of plant roots harvested at relative young age. Yet, the qualitative responses recorded under controlled conditions were considered as indicative of processes, which could 

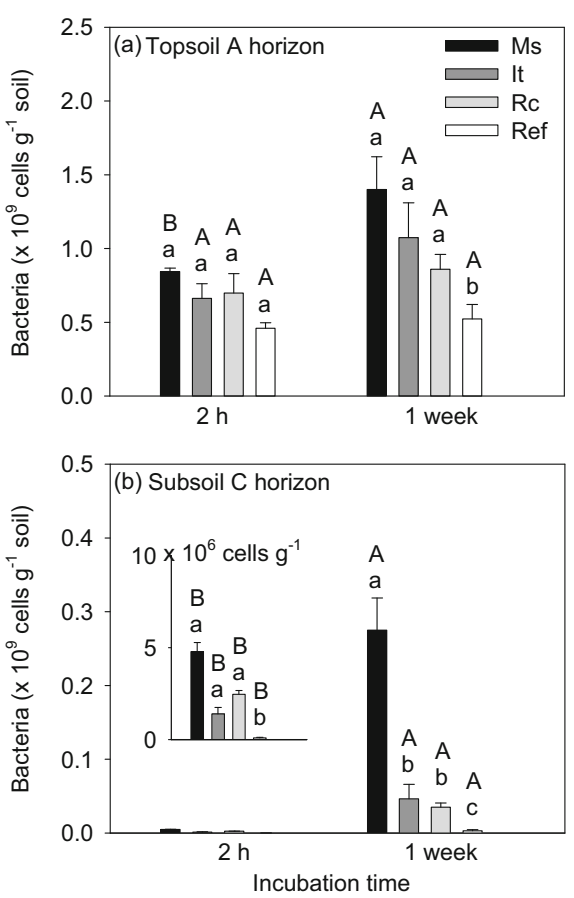

Fig. 6 Bacterial numbers (estimated from 16S rRNA gene copies) in (a) topsoil (A horizon) and (b) subsoil (C horizon) after incubation with root biomass or reference treatment (Ref, deionized water) for $2 \mathrm{~h}$ and 1 week. Data are means \pm standard error $(n=3)$. Significant differences $(P<0.05)$ between incubation times (for each treatment) are indicated by different uppercase letters; significant differences between treatments (at each incubation time) are indicated by different lowercase letters. Root biomasses: Ms, M. sativa; It, I. tinctoria; Rc, $R$. crispus

prevail also under less optimal conditions, though likely at slower rates.

The cumulative root-induced carbon losses after 20 weeks were significantly higher in topsoil $(58 \%$ of added carbon) than in subsoil (32-41\% of added carbon). This difference could be interpreted in relation to the duration of the incubation (i.e., merely reflecting higher mineralization rates in topsoil than in subsoil), but potentially also in relation to different soil properties with subsoils having higher potential of organic carbon protection by mineral association, more severe nutrient limitation, and/or lower metabolic versatility than topsoil (Fontaine et al. 2007; Heitkötter et al. 2017; Rumpel and Kögel-Knabner 2011; Salomé et al. 2010). On a longer time-scale, Sanaullah et al. (2011) found that more root-derived carbon was retained in subsoil than in topsoil after 6 months of incubation (using wheat roots in litterbags), whereas equal amounts were retained after 3 years, i.e., indicating merely a difference in mineralization rates. Similar results were reported by Li et al. (2015) and could also be partly inferred from the GN treatments in the present study, where initial differences in topsoil and subsoil carbon losses prevailed after 1 week, but were leveled out after 20 weeks of incubation. These results suggest that lower carbon losses in deep soil layers may be the result of delayed mineralization rather than greater protection through mineral association or absence of metabolic potential. Additionally, potential priming effects may be higher in topsoil than in subsoil when organic compounds are added (Meyer et al. 2018), which could likewise contribute to the generally higher net carbon loss in the topsoil. In the present deep subsoil, with very low SOC concentration $\left(0.4 \mathrm{mg} \mathrm{g}^{-1}\right)$, priming effects were expectedly of minor importance. For example, mineralization of as much as $15 \%$ of the SOC due to priming (Fierer et al. 2003a; Heitkötter et al. 2017) would contribute to only $6 \%$ of the average $\mathrm{CO}_{2}$ production induced by roots in the subsoil $\mathrm{C}$ horizon.

$\mathrm{N}$ limitation of microbial activity in subsoil

Addition of root biomass increased $\beta$-glucosidase activity, and this increase was positively correlated to root TN concentrations. Although the correlation analyses were based on a relatively small sample number (and could be sensitive to single observations), this pattern aligned with the bacterial population growth that was most pronounced for the N-rich $M$. sativa root amendments. Moreover, in MicroResp assays, the N containing substrate NADG resulted in higher respiration rates than glucose devoid of N. Collectively, these results indicate that microbial activity was limited by soil $\mathrm{N}$ availability when carbon substrates were added, consistent with other studies (Fierer et al. 2003a; Fontaine et al. 2007; Heitkötter et al. 2017). Stimulation of microbial growth and activities was linked to TN of added roots (and GN) at all three soil depths, but the importance may be higher for microbial functions in subsoil compared to topsoil. In topsoil, where the inherent microbial biomass and activity was high, addition of root biomass only resulted in two to three fold relative increase in microbial parameters (i.e., $\beta$-glucosidase activity, CSU, and bacterial cell numbers), whereas the relative increase in subsoils treated with $\mathrm{N}$ rich materials ( $M$. sativa and $\mathrm{GN}$ ) was two to three orders of magnitude. 


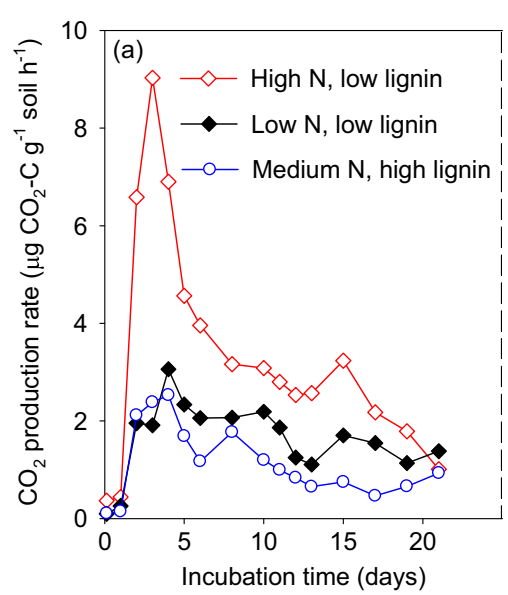

Fig. 7 Conceptual interpretation of the interacting control of nitrogen $(\mathrm{N})$ availability and root litter chemistry on mineralization of root biomass in subsoil. Data were compiled from Table 3, Fig. $\mathrm{S} 2$, and Fig. $\mathrm{S} 5$ to show the dynamics of $\mathrm{CO}_{2}$ production in subsoil during incubation with root biomass (panel a) and after $\mathrm{N}$ (nitrate, $\mathrm{NO}_{3}{ }^{-}$) addition to induce mineralization of residual root carbon

Implication for subsoil carbon sequestration

Deep-rooted plants can be implemented in agroecosystems, but are also common in natural biomes (Canadell et al. 1996; Jackson et al. 1996) where deep rooting has importance for water and nutrient uptake, as well as for carbon cycling (Lynch and Wojciechowski 2015). Our results suggest that subsoil root carbon turnover was limited by microbial $\mathrm{N}$ availability. Since low $\mathrm{N}$ concentrations are common in subsoils (Fierer et al. 2003b; Jia et al. 2017; Tian et al. 2016), this limitation could represent a general mechanism for retention of plant carbon in deep soil layers. However, the persistence of this retained plant carbon pool may not be permanent and could be subject to decomposition by addition of $\mathrm{N}$. Direct or indirect agricultural practices that promote $\mathrm{N}$ distribution in deep soil profiles could therefore increase carbon losses in subsoils. Yet, such carbon losses would be associated with microbial growth and potential longterm stabilization of anabolic microbial carbon remains (Cotrufo et al. 2015; Liang et al. 2017), representing a fraction of the metabolized plant carbon.

In agricultural subsoils influenced by $\mathrm{NO}_{3}{ }^{-}$leaching, ingrowth of deep roots may assimilate and remove $\mathrm{N}$, thereby lowering the potential for microbial carbon mineralization in addition to providing input of plant-derived carbon. Conversely, introduction of deep roots and exudates may also activate a dormant subsoil microbiome and

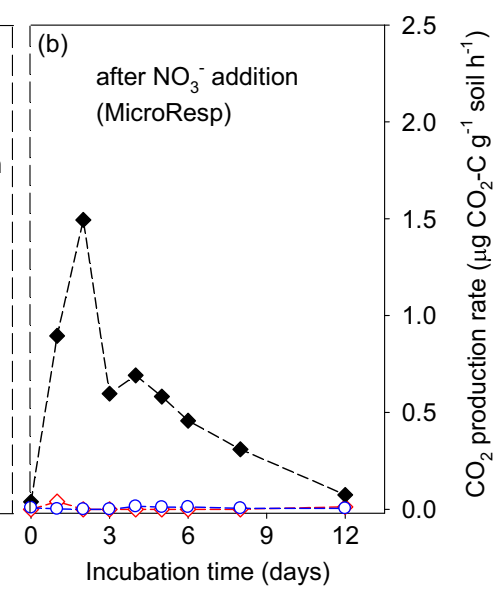

after 20 weeks (panel b) as tested by MicroResp assays. Root biomasses were from $M$. sativa (high $\mathrm{N}$, low lignin), A. vulgaris (low N, low lignin), and $M . \times$ giganteus (medium N, high lignin). Data are mean of three replicates with error bars omitted for clarity. Note the difference in scales between panel $\mathrm{a}$ and $\mathrm{b}$

induce carbon turnover potentially priming the metabolism of native subsoil carbon (Bernal et al. 2017). It seems, therefore, that the resulting carbon dynamics related to deep root ingrowth in subsoils is closely linked to the dynamics of nutrient availability, here specifically illustrated for $\mathrm{N}$, but potentially also related to other major elements like P and S (Heitkötter et al. 2017).

In addition to the role of subsoil $\mathrm{N}$, our results showed that chemically complex carbon fractions in root biomass, such as LIG, can influence the dynamics of carbon storage in deep soil. Even though microbial activity may be enhanced by root carbon and nutrient input, cultivation of plant species such as $M$. $\times$ giganteus with high root concentrations of chemically recalcitrant compounds may represent a mechanism for combined stabilization of carbon from anabolic microbial remains and plant-derived carbon fractions (Liang et al. 2017). Yet, $M . \times$ giganteus has a relatively shallow root distribution (Monti and Zatta 2009) and for subsoil carbon sequestration other deep-rooted plant species with appropriate root chemical characteristics should probably be selected.

As a synthesis, our study was compatible with a concept of $\mathrm{N}$ availability and root chemically recalcitrant compounds (such as LIG) interacting on control of subsoil carbon turnover (Fig. 7). Firstly, root biomass high in $\mathrm{N}$ concentration and low in recalcitrant carbon may be readily mineralized in subsoils (Fig. 7a; high $\mathrm{N}$, low 
lignin). Yet, even if recalcitrant carbon is low, the mineralization may be limited when biomass $\mathrm{N}$ is low (Fig. 7a; low N, low lignin); but this limitation may be alleviated by exogenous N (Fig. 7b). Secondly, inherent chemical recalcitrance may further contribute to delayed carbon mineralization, even when root $\mathrm{N}$ limitation is not prevailing (Fig. 7a; medium N, high lignin); this limitation is not alleviated by exogenous $\mathrm{N}$ (Fig. 7b).

Further research should focus on exploring suitable crops and management options, which are beneficial for stimulating carbon storage, for example based on combined assets of providing high crop yields, efficient $\mathrm{N}$ uptake, and chemically complex root fractions allowing stabilization of carbon fractions related to both metabolic and anabolic microbial activity.

Acknowledgements We thank the technical staff at Foulumgaard Experimental Station for assistance in soil sampling, Bo Vangsø Iversen for assistance in profile description, Charlotte Kjærgaard for guidance on redox measurements, Tanka Kandel for guidance on soil respiration measurements, Leanne Peixoto for comments on DNA analyses, and Kristian Thorup Kristensen for providing cylinders with plant samples. Further, the skilled laboratory assistance of Bodil Stensgaard, Margit Paulsen, and Mette Sahl Haferbier is highly acknowledged. We finally thank Bent T. Christensen and anonymous journal reviewers for helpful suggestions to the manuscript.

Funding This work was supported by the Deep Frontier project funded by the Villum Foundation.

\section{Compliance with ethical standards}

Conflict of interest The authors declare that they have no conflict of interest.

\section{References}

Abiven S, Heim A, Schmidt MW (2011) Lignin content and chemical characteristics in maize and wheat vary between plant organs and growth stages: consequences for assessing lignin dynamics in soil. Plant Soil 343:369-378

Alexander M (1977) Introduction to soil microbiology, 2nd edn. John Wiley and Sons, New York

Amundson R (2001) The carbon budget in soils. Annu Rev Earth Planet Sci 29:535-562

Aulen M, Shipley B (2012) Prediction of in situ root decomposition rates in an interspecific context from chemical and morphological traits. Plant Soil 355:41-49

Banning N, Lalor B, Cookson W, Grigg A, Murphy D (2012) Analysis of soil microbial community level physiological profiles in native and post-mining rehabilitation forest: which substrates discriminate? Appl Soil Ecol 56:27-34

Berg B, Laskowski R (2005) Litter decomposition: a guide to carbon and nutrient turnover. Adv Ecol Res 38:1-421

Bernal B, Megonigal JP, Mozdzer TJ (2017) An invasive wetland grass primes deep soil carbon pools. Glob Chang Biol 23: 2104-2116

Bertrand I, Chabbert B, Kurek B, Recous S (2006) Can the biochemical features and histology of wheat residues explain their decomposition in soil? Plant Soil 281:291-307

Campbell CD, Chapman SJ, Cameron CM, Davidson MS, Potts JM (2003) A rapid microtiter plate method to measure carbon dioxide evolved from carbon substrate amendments so as to determine the physiological profiles of soil microbial communities by using whole soil. Appl Environ Microbiol 69: 3593-3599

Canadell J, Jackson R, Ehleringer J, Mooney H, Sala O, Schulze ED (1996) Maximum rooting depth of vegetation types at the global scale. Oecologia 108:583-595

Carlsson G, Huss-Danell K (2003) Nitrogen fixation in perennial forage legumes in the field. Plant Soil 253:353-372

Chirinda N, Elsgaard L, Thomsen IK, Heckrath G, Olesen JE (2014) Carbon dynamics in topsoil and subsoil along a cultivated toposequence. Catena 120:20-28

Cotrufo MF, Soong JL, Horton AJ, Campbell EE, Haddix ML, Wall DH, Parton WJ (2015) Formation of soil organic matter via biochemical and physical pathways of litter mass loss. Nat Geosci 8:776-779

Eivazi F, Tabatabai M (1988) Glucosidases and galactosidases in soils. Soil Biol Biochem 20:601-606

Elsgaard L, Andersen GH, Eriksen J (2002) Measurement of arysulphatase activity in agricultural soils using a simplied assay. Soil Biol Biochem 34:79-82

Fierer N, Allen AS, Schimel JP, Holden PA (2003a) Controls on microbial $\mathrm{CO}_{2}$ production: a comparison of surface and subsurface soil horizons. Glob Chang Biol 9:1322-1332

Fierer N, Schimel JP, Holden PA (2003b) Variations in microbial community composition through two soil depth profiles. Soil Biol Biochem 35:167-176

Fontaine S, Barot S, Barré P, Bdioui N, Mary B, Rumpel C (2007) Stability of organic carbon in deep soil layers controlled by fresh carbon supply. Nature 450:277-280

Gee GW, Bauder JW (1986) Particle-size analysis. In: Klute A (ed) Methods of Soil Analysis: Part 1 - Physical and Mineralogical Methods. American Society of Agronomy and Soil Science Society of America, Madison, pp 383-411

Godfray HCJ, Beddington JR, Crute IR, Haddad L, Lawrence D, Muir JF, Pretty J, Robinson S, Thomas SM, Toulmin C (2010) Food security: the challenge of feeding 9 billion people. Science 327:812-818

Heinze S, Ludwig B, Piepho HP, Mikutta R, Don A, WordellDietrich P, Helfrich M, Hertel D, Leuschner C, Kirfel K (2018) Factors controlling the variability of organic matter in the top-and subsoil of a sandy Dystric Cambisol under beech forest. Geoderma 311:37-44

Heitkötter J, Heinze S, Marschner B (2017) Relevance of substrate quality and nutrients for microbial C-turnover in top-and subsoil of a Dystric Cambisol. Geoderma 302:89-99

ISO (2004) Water quality - determination of phosphorus - ammonium molybdate spectrometric method. ISO 6878:2004. ISO International Organization for Standardization, Geneva 
Jackson R, Canadell J, Ehleringer J, Mooney H, Sala O, Schulze E (1996) A global analysis of root distributions for terrestrial biomes. Oecologia 108:389-411

Jia J, Feng X, He JS, He H, Lin L, Liu Z (2017) Comparing microbial carbon sequestration and priming in the subsoil versus topsoil of a Qinghai-Tibetan alpine grassland. Soil Biol Biochem 104:141-151

Ju XT, Xing GX, Chen XP, Zhang SL, Zhang LJ, Liu XJ, Cui ZL, Yin B, Christie P, Zhu ZL (2009) Reducing environmental risk by improving $\mathrm{N}$ management in intensive Chinese agricultural systems. Proc Natl Acad Sci U S A 106:3041-3046

Kandel TP, Laerke PE, Elsgaard L (2016) Effect of chamber enclosure time on soil respiration flux: a comparison of linear and non-linear flux calculation methods. Atmos Environ 141: 245-254

Kjaergaard C, Heiberg L, Jensen HS, Hansen HCB (2012) Phosphorus mobilization in rewetted peat and sand at variable flow rate and redox regimes. Geoderma 173:311-321

Lane DJ, Pace B, Olsen GJ, Stahl DA, Sogin ML, Pace NR (1985) Rapid determination of 16S ribosomal RNA sequences for phylogenetic analyses. Proc Natl Acad Sci U S A 82:69556959

Li A, Fahey TJ, Pawlowska TE, Fisk MC, Burtis J (2015) Fine root decomposition, nutrient mobilization and fungal communities in a pine forest ecosystem. Soil Biol Biochem 83: $76-83$

Liang C, Schimel JP, Jastrow JD (2017) The importance of anabolism in microbial control over soil carbon storage. Nat Microbiol 2:17105

Lindedam J, Magid J, Poulsen P, Luxhøi J (2009) Tissue architecture and soil fertility controls on decomposer communities and decomposition of roots. Soil Biol Biochem 41:10401049

Lorenz K, Lal R (2005) The depth distribution of soil organic carbon in relation to land use and management and the potential of carbon sequestration in subsoil horizons. Adv Agron 88:35-66

Lynch JP, Wojciechowski T (2015) Opportunities and challenges in the subsoil: pathways to deeper rooted crops. J Exp Bot 66: 2199-2210

Machinet GE, Bertrand I, Chabbert B, Watteau F, Villemin G, Recous S (2009) Soil biodegradation of maize root residues: interaction between chemical characteristics and the presence of colonizing micro-organisms. Soil Biol Biochem 41:12531261

Maeght JL, Rewald B, Pierret A (2013) How to study deep roots and why it matters. Front Plant Sci 4:299. https://doi. org/10.3389/fpls.2013.00299

Meyer N, Welp G, Rodionov A, Borchard N, Martius C, Amelung W (2018) Nitrogen and phosphorus supply controls soil organic carbon mineralization in tropical topsoil and subsoil. Soil Biol Biochem 119:152-161

Monti A, Zatta A (2009) Root distribution and soil moisture retrieval in perennial and annual energy crops in northern Italy. Agric Ecosyst Environ 132:252-259

Olesen JE, Askegaard M, Rasmussen IA (2000) Design of an organic farming crop-rotation experiment. Acta Agric Scand Sect B Soil Plant Sci 50:13-21

Petersen SO, Frohne PS, Kennedy AC (2002) Dynamics of a soil microbial community under spring wheat. Soil Sci Soc Am J 66:826-833
Petersen SO, Hoffmann CC, Schafer CM, Blicher-Mathiesen G, Elsgaard L, Kristensen K, Larsen SE, Torp SB, Greve MH (2012) Annual emissions of $\mathrm{CH}_{4}$ and $\mathrm{N}_{2} \mathrm{O}$, and ecosystem respiration, from eight organic soils in Western Denmark managed by agriculture. Biogeosciences 9:403-422

Picon-Cochard C, Pilon R, Tarroux E, Pagès L, Robertson J, Dawson L (2012) Effect of species, root branching order and season on the root traits of 13 perennial grass species. Plant Soil 353:47-57

Powlson DS, Gregory PJ, Whalley WR, Quinton JN, Hopkins DW, Whitmore AP, Hirsch PR, Goulding KWT (2011) Soil management in relation to sustainable agriculture and ecosystem services. Food Policy 36:S72-S87

Pretty J (2008) Agricultural sustainability: concepts, principles and evidence. Phil Trans R Soc B Biol Sci 363:447-465

Prieto I, Stokes A, Roumet C (2016) Root functional parameters predict fine root decomposability at the community level. J Ecol 104:725-733

Raiesi F (2006) Carbon and $\mathrm{N}$ mineralization as affected by soil cultivation and crop residue in a calcareous wetland ecosystem in Central Iran. Agric Ecosyst Environ 112: 13-20

Redin M, Guénon R, Recous S, Schmatz R, De Freitas LL, Aita C, Giacomini SJ (2014) Carbon mineralization in soil of roots from twenty crop species, as affected by their chemical composition and botanical family. Plant Soil 378:205-214

Ribaudo M, Delgado J, Hansen L, Livingston M, Mosheim R, Williamson J (2011) Nitrogen in agricultural systems: Implications for conservation policy. Economic Research Report 127. United States Department of Agriculture, Economic Research Service

Rumpel C, Kögel-Knabner I (2011) Deep soil organic matter - a key but poorly understood component of terrestrial $\mathrm{C}$ cycle. Plant Soil 338:143-158

Salomé C, Nunan N, Pouteau V, Lerch TZ, Chenu C (2010) Carbon dynamics in topsoil and in subsoil may be controlled by different regulatory mechanisms. Glob Chang Biol 16: 416-426

Sanaullah M, Chabbi A, Leifeld J, Bardoux G, Billou D, Rumpel C (2011) Decomposition and stabilization of root litter in topand subsoil horizons: what is the difference? Plant Soil 338: 127-141

Schrumpf M, Kaiser K, Guggenberger G, Persson T, KögelKnabner I, Schulze ED (2013) Storage and stability of organic carbon in soils as related to depth, occlusion within aggregates, and attachment to minerals. Biogeosciences 10: 1675-1691

Sørensen NK, Bülow-Olsen A (1994) Plantedirektoratets fælles arbejdsmetoder for jordbundsanalyser. Plantedirektoratet, Lyngby (in Danish)

Stoddard SF, Smith BJ, Hein R, Roller BR, Schmidt TM (2014) $r r n$ DB: improved tools for interpreting rRNA gene abundance in bacteria and archaea and a new foundation for future development. Nucleic Acids Res 43:D593-D598

Taghizadeh-Toosi A, Olesen JE, Kristensen K, Elsgaard L, Ostergaard HS, Laegdsmand M, Greve MH, Christensen BT (2014) Changes in carbon stocks of Danish agricultural mineral soils between 1986 and 2009. Eur J Soil Sci 65:730 740 
Taylor J, Wilson B, Mills MS, Burns RG (2002) Comparison of microbial numbers and enzymatic activities in surface soils and subsoils using various techniques. Soil Biol Biochem 34: 387-401

Tian QX, Yang XL, Wang XG, Liao C, Li QX, Wang M, Wu Y, Liu F (2016) Microbial community mediated response of organic carbon mineralization to labile carbon and nitrogen addition in topsoil and subsoil. Biogeochemistry 128:125139

Turner S, Pryer KM, Miao VP, Palmer JD (1999) Investigating deep phylogenetic relationships among cyanobacteria and plastids by small subunit rRNA sequence analysis. J Eukaryot Microbiol 46:327-338
Van Soest PJ (1963) Use of detergents in the analysis of fibrous feeds. II A rapid method for the determination of fiber and lignin. J Assoc Off Agric Chem 46:829-835

Vinther FP, Elsgaard L, Jacobsen OS (2001) Heterogeneity of bacterial populations and pesticide degradation potentials in the unsaturated zone of loamy and sandy soils. Biol Fertil Soils 33:514-520

Zar JH (2010) Biostatistical analysis, 5th edn. Prentice Hall, Inc., Upper Saddle River

Zhang X, Wang W (2015) The decomposition of fine and coarse roots: their global patterns and controlling factors. Sci Rep 5: 9940. https://doi.org/10.1038/srep09940 